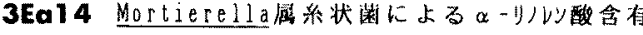
油脂のEPA含有油脂への変換

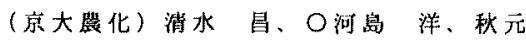
健吾*，新免芳史*，山田秀明

1. 目的 Mortierella 局糸状菌のいくつかが、I1

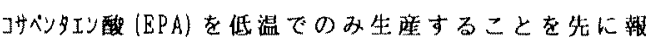
告したはっ。しかし低温培蓝は大量生産に不利なた め、常湿での生痤を目指したところ、ローリノり酸を含

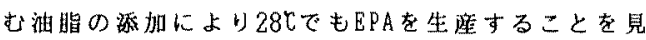
出した。本埌では常温におけるこれら油脂のEPA含有 油脂への変換条件について報告する。

2. 方法・結果当砳究空保存のMortierella属加を

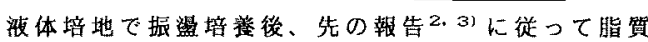
の抽出・分析を行った。㮞々な油を添加して28てで堷 蕃したところ、フ引忆酸を生座することのできる菌 株では、7マニ油や大豆油の成分がEPAに変換されるこ

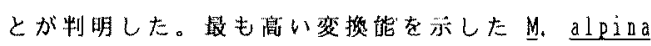
20-17は、7マこ油無添加の呧温条件下ではEPAの篦䅡

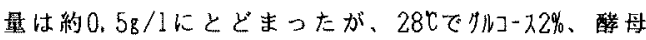

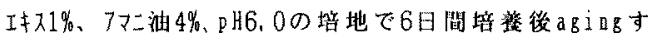
ることにより、1.35g/10BPAを生庄した。また、EPA の生合成経路についても㛟討した。

1) H, Yamada et all, J, Am, Oil Cbem, Soc, 64, 1254 (1987). 2) S. Shimizu et al. BBRC, in press.

3) H, Yaluada et al. Agric. Biol, Chem, 51, 785 (1987). *サントリー(政)

\section{Ea 16}

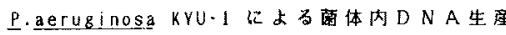

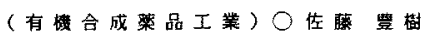

$$
\begin{aligned}
& \text { (九大食化工) 石崎文彬 }
\end{aligned}
$$

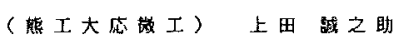

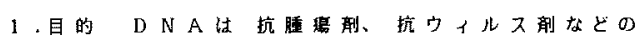

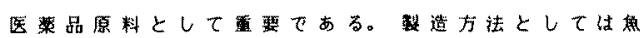
頪白子を原料として抽出精鹤する力法加一般的てあ

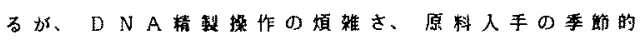

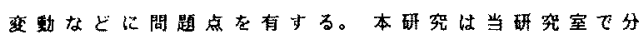

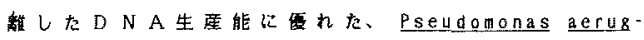
inosa kyu-1株在用いて培在行い, DNA生成条件 の至道化を行うことを目的としたものである。

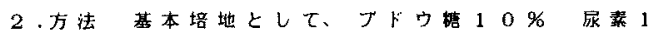
$.4 \% \mathrm{CSL} 3.0 \% \quad \mathrm{Na} 2 \mathrm{PO} 41.0 \% \mathrm{Mg}$

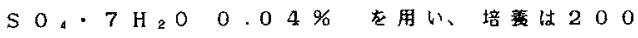

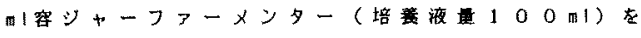

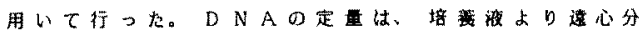

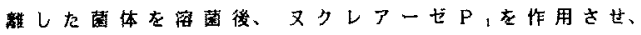

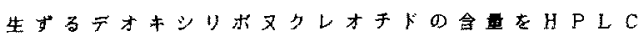
て潰することにより行った。

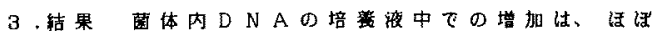

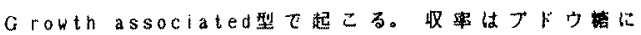

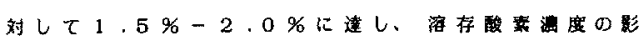
讄を大く受ける。

文解 T.Hara S.Ueda J.Appl.B iochem. 3, $1-10(1981)$
3Ea15 蟭䐝がらの5’ーグアニル酸の生座 〔一槽逐次培域・反応法ブロセス〕 （協和発酸柬京研・技研）○藤尾達郎、 丸山明彦、青山良秀・、古屋晃

1. 目的調味料として用いられている5’ーグアニ

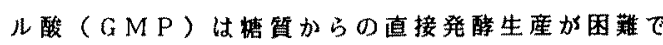
あるため、5’一キサンチル酸（XMP）の発醇液中 て XMP $\rightarrow$ GMPの転換を行うことによる直接発醇 生歴法に近似の工業生産フ口セスを開発する。

2.方法XMPの発醉生産およびXMPからGM $P へ の$ 転換には、それぞれB.ammonlageneskY13215 お小びKY13510株を用いた。転换反応には200mlビ 一カーまた汹5しージャ一を用いた。

3. 結果 グルコースを炭素源とする培地にKY1321 5 株を $30^{\circ} \mathrm{C}$ で培羡し、62時間で $70 \mathrm{mg} / \mathrm{ml}$ の 5 '-XMP・

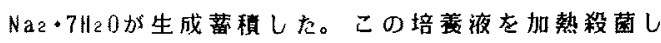
グルコース・リン酸などを添加したのち、別に㮔培 翊を行ったKY13510株を植菌し、さらに約20時間培 蕾を行った。残精が無くなった時点で温度を $42^{\circ} \mathrm{C} に$ 上ぜ、グルコース・リン酸・界面活性郕などを添加 して約15時閣反応したところ、5'-GMP・Na2・7H20が $40 \mathrm{mg} / \mathrm{mI}$ 生成蓄箖した。XMP発醉液を加熱殺菌する ことによるXMPの分解は無視し得る程度であった。 培楸・反応の過程における容棈变化を補正したXM P方 G MPへの転换寗は80〜85\%てあった。

文献. 藤尾々、J.ferment.technol.,62,131(1984)

3Ep1 フェルラ酸資化性菌の变異株 HF-1124 の Characterization

（東大㤟化）○酉山和久、大森俊雄、 児玉 徹

1.目的 コェルラ酸資化性菌 Pseudomonas HF-1 を変異処理することによって、フェルラ酸からブロ 卜カテキン酸（PCA）を蓄稹する变異株 HF-1124

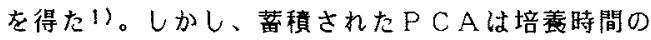
経過と共に減少してしまうのて、その機構を解明し、 制御することを目的とした。

2. 方法 5 1三角フラスコ、21ジャーファーメ ンターを用いて培義した。基啠および生成物の定望 にはHPLCを用いた。PCA、没食子酸（GA）、 カテコールに対する分解活性は酸素電亟法によって 調べた。菌体破砕にはコレンチブレスを用いた。 3. 結果 変異株诂弱いP C A 分解活性をむつが、 GA 分解活性が培䇑時閒の経過とともに增大した。 Cell free にすると、PCA分解活性は $50,000 \times g$ の超遠心上清にあった。また、沈殿の可溶化部分に 岓、強いGA分解活性と弱いNADPH 依存性P C A 分解活性があった。このことより、本菌株がP C A をオルト開裂とは別の経路で分解している可能性が 示唆された。

文献 1)大森、香山、児玉；日本農芸化学会62年度 大会要旨集、P 437 
3Ep2

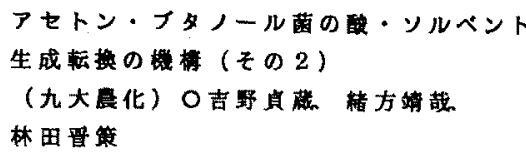

1. 目的フタノールリッチ生成满Clostridium sacchasopesbutylacetonicum N-4枺のDegeneration (DGN)株は、ソルベント生成能が頙著に低下している

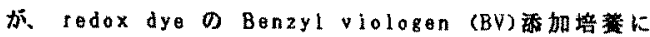
より、ソルベント生成、特にフタノール生成能が回 復する。本報で、BVを電子受容体として利用する

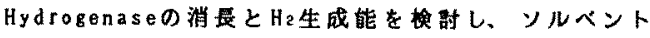
生成低下の原因を明らかにしょうとした。

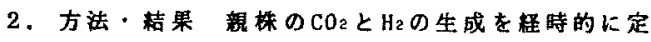
量したところ、对数增㱠期では1：1、ソルベント生 成が開始する定労期ては3：1となり、NADHz生成のた めH2放出が排制されていた。これに対しDGN株では培

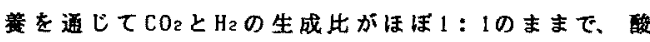
・ソルベント生成転はるれなかった。一方親株

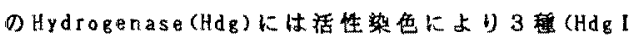
II，田つが锚めら九、特にンルベント生成期にHdg III が 出現したが、DGN株てはHdg亚活性が琵められなかっ た。DGN株菌体では山上取り还み能が著しく低下してい ることから、HdgIII C. pasteurianumにみられる Hdg II (uptake)に似て、H2取り远み活性を有するもの と推考さ九、DGNに株にけるHdg而の久陷が、ソルベ ント生成能低下の要因と考蔡された。

3Ep4

緑藻による水菜生産(1 11 )

混合培意システムにおける水素生産性の向上

(服大菜) ○淞阙莫二郎 名和義仁 宮本和久 三浦喜温

1。目的䟿藻は、暗嫌気条件下、落皘した内部基 質加ら水素の他に、種々の発醇産物を生成する。ま た、光合成細菌は、明古るいは暗嫌気条件下、有卙 酸等加ら水菜室生成する。演者ら法、暗嫌気条件下

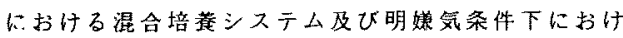
る光合成細菌の光水素発生の利用について報告した

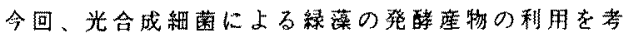
虑し、種々の問題点について検討した。

2. 万法 緑藻Chlamydomonas reinhardti $\varepsilon$ 光合

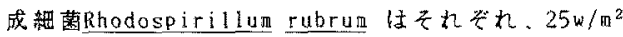
$200 \mathrm{w} / \mathrm{s}^{2}$ の光照射下 $30^{\circ} \mathrm{C}$ で培養し、集菌した。暗水

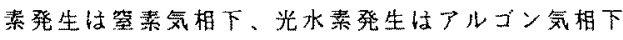
$30^{\circ} \mathrm{C}$ 振とう娞觀察した。水素は、ガスクロマトグラ フ法、他の発嗳物物䣼法により定量した。

3. 結果 c. reinhardtii k执いて、水嘫生産培地 の琣装制限によるデンプン分解及び発醅産物生成八 の影帤はなく、䆟素制限培地の利用が可能となった。

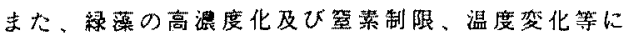
よる增殖抑制を行い内部基筫の蓄楮量を增加させ、 をの分解促進を計った。その結果、発醉産物の生成 量の增加が認められた。さらに、明期での光合成細

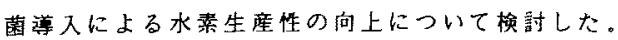

$3 E$ E 3 エタノール・イソ吉草酸産生萰Clostridium acetobutyricum AS 株の代碀系

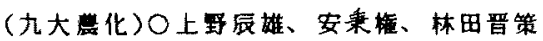
1.目的 Clostridium acetobutyricum AS 制は、工 タノール及びイソ吉草酸を代誰生産物とする新規な 菌株である。本報では、本菌株の代謝系について模 討した。

2.万法ブタノール生産菌 C. saccharoperbutylacetonicum N1.4 株を照としてAS 株の培盖を行い

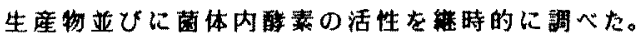
thiolase活性测定はSter而らの方法によった。 3.结果 N1-4 株で结、菌体蛋白当りの thiolase活 性は、培薪 16 時間で最高に達し、以後城少したが、 その活性は保持された。これに対し、AS株では8時

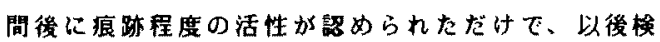
出されなかった。AS株の発醉生産物は、培筑8時閒 後に山僅少量の酪酸が検出されたが速やかに代䛠さ 九、thiolase活性の消失とともに、エ夕ノール及び イソ吉草酸だけ加生歷された。以上の結果から、本

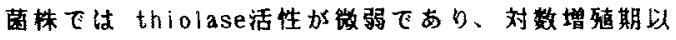
後消失するため、アセトン及びブタノールは生産さ れず、エタノール及しイソ吉草酸加生産されるもの と考察される。

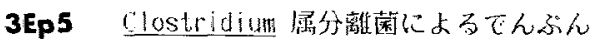
加らの多ノール生成

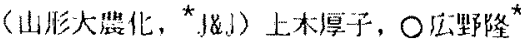

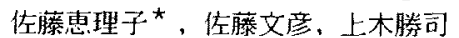

1.目的 我々は廃水の婔気的分解に関与す万嫌気性

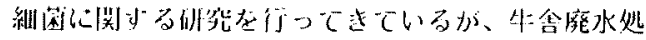
理槽より、種々の基算からエタノールを高率で生成 するClostridium属の1菌㧣を分離した。この菌株の

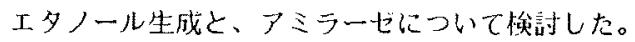
2.方法 培犌は基本的にHungateの嫌気性細菌培袁法 に従った。発醅生成物はガスクロマトグラフィーで、 還元㥉はDNPA法で定量し、アミラーゼ活性の測定は Blue-Value法で行った。

3.結果 $\mathrm{N}_{2} 95 \%+\mathrm{CO}_{2} 5 \%$ 気相でグルコース1学を基筫と してこの囷を培蜜した場合、エ夕ノールは約80m生 成された。この時酢酸屯的10mM生成されたが、乳酸 を含む他の脂肪酸は生成されなかった。 $\mathrm{CO}_{2} 100$ 年気相

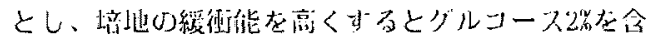
む培地ての工多ノール生成量は約150mMになった。 の菌株はグルコース以外にも、キシロース、セロビ 才ース、でんぷん等、多棑な基筫からエ夕ノールを 効率よく生成したが、セルロースは利用しなかった。 可溶性でんぷん2\%で培養した時の生成量は最高で約 140mMであった。この囷の培甆上清中に娭出されるア ミラーゼについてその生成条件を検討すると共に、

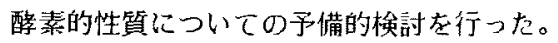


$3 E p 6$ Lactobacillus bulgaricus フロトブラスト の高效率再生条件

(明治哹業へルスサイエンス研究所)

○竹友直生

1.目的産業上有用なLactobacillus属乳酸桿菌の ブロトブラスト再生法は、末だに磼立しておらず、 これを利用した遗伝有種に関する報告むきわめて少 ない。我々结、L.bulgaricusのフロトフラスト形成 並びに再生条件につき检璟してきたが，高効率再生 法を見いだしたので報告する。

2 .方法 L.bulgaricusについて、Lee-Vickner'b の再生培地をとにして、培地条件の最適化を行な つた。丁ロトフラストは、形熊的に9％上上の絊 胞が球状化したものを用いた。

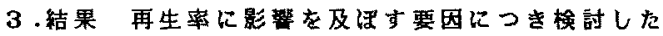
結果、漫透压安定詴としてのラフィノース0.2M，ぜう チン $25 \%$ 、L.bulgaricusの粗新胞壁または加熱処 理囷体添加等の最通化培地により再生率は著しく高 くなった。これを用いて模路ると、再生率の高い

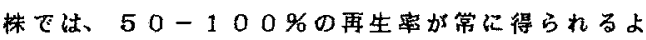
うになった。これらは、细胞融合や形哲転挨在梌討 する上で有效な材料と考えられる。

门伤々木隆ら：日本豊芸化学会昭和61、62 年慶大会諎演要旨集

2) Lee-Wickner, L.J. and Chassy,B.M. :

Appl.Environ.Miclobiol., $48(5) 994(1984)$

$3 E p 8$ 乳酸菌のブロトブラスト化と再生

（哣市工研）○小林络，唅山圭一郎

1.目的视藕は食品工業などで広く用いられて いるか，育種によって政良すべき点む多い。本研究

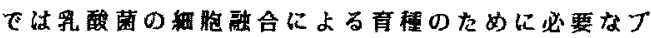
ロトフラスト化と再生の条件を梌期した。

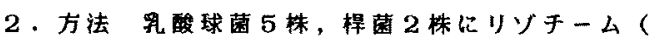
6 $\sim 120 \mu \mathrm{g} / \mathrm{ml})$ およU Streptomyces globisporus 18290 endo-N-acetylmuramidase $(M-1,2 \sim 35$ $\mu \mathrm{g} / \mathrm{ml})$ を $3 \mathrm{mM} \mathrm{MgCl}$ を合む $30 \mathrm{mM} \mathrm{Tris-HCl}$ 㣪衙 (pH 8．0）中， $37^{\circ} \mathrm{C}$ て作用させ，溶落を濁度で道跡 することによりブロトフラスト化を娭討した。フロ トブラストよりの再生は, ショ榙, $\mathrm{MgCl}_{2}, \mathrm{CaCl}_{2}$, ぜラチンなどを倉む再生培地で行った。

3.結果プロフコスト化については，用いた菌 株に対して，リソチームとM-1の併用が，それぞ れを単独で用いるより速やかに滄度低下が起こし， 効果的であると考光られた。再生は2.5 $\mathrm{mM} \mathrm{MgCl}$ ， $2.5 \mathrm{mM} \mathrm{CaCl} 2,2.5 \%$ ぜラチンを合む培地でょく起 こり，再生密に関しても，単一酸素処理した菌株の 場合 $(1 \sim 2.5 \%)$ よりむ二つの酸素を併用した菌株 の場合（77\%以上）の方が優れていることがわかっ た。
3Ep7 Brevibacterium ammoniagenes のプロトブ

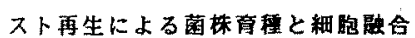

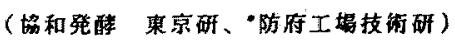

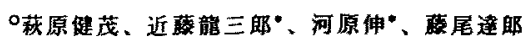

1.目的 Brevibacteriun ammoniagenes はイノシン醂

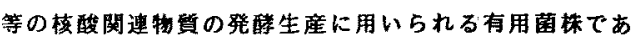
る。我々性既に本菌数性株のプロトプラスト化と再生に

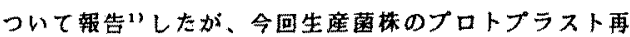
生並びに細盷融合について积討した。

2.方法・細盷聂合は、目的菌梅をブロトフラストとし 混合後、Sucrose 0.5 K、PEG-400040\%等を含を禹张洛 渡中で10分間処理しておこなった。

3.結果 ①ノシン酸生産菌株KY13363のプロトブラ スト再生類度は野性株に比へて臤めて低かったが、a）共 試菌培時のグリシン添加浱度低下、b)再生培地への牛 血清アルブミン添加、によって大幅に向上した。また、 再生㧼中に親株よりもイノシン酸生産能の高い菌株が出 現し、この菌株は搪消緊が若千革いが、イノシン酸蓄棈 は $22 \mathrm{~g} / 1$ (新林 $18.5 \mathrm{~g} / 1$ ) と約 2 割向上していた。

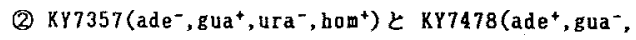
$\left.\mathrm{ura}^{+}, \mathrm{hom}^{-}\right)$を融合処理した結果、( $\left(\mathrm{gua}^{+}, \mathrm{ura}^{+}\right)$となった

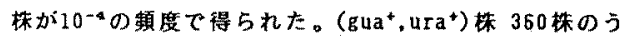

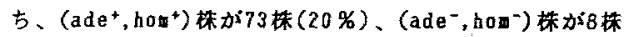
(2\%)存在し、非莩択マーカーの組搝えもおこっていた。 組撸六林のとんどは通伀的に安定たった。

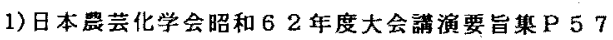

3Ep9

ピフィスス菌のフロトフラスト蚝合 第1報 フロトフラスト調法の梌討

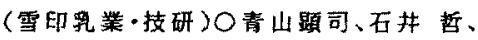
㩑場资、岩崎泰介、中里溥志

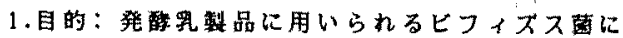

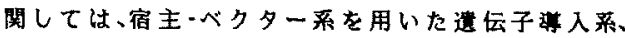
或は细胞融合等の遗伝学的手法は末だ開無されて いない。そこた、演者らはフロトブラスト融合 法による本菌の充種を目的として、本菌のフロト フラストの調製法の梌尉を行った。

2. 方法: Bifidobacterium pseudolongum SBT2908, B.longum M205 の2菌株について種々の条件下て

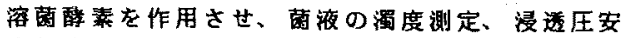

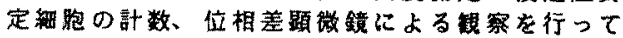
プトブラスト形成のための至適条件を探䇣した。 3.结果: B.pseudolongum SBT2908株は、 $3 \mathrm{mM} \mathrm{MgCl}$ $0.3 M$ rafinose t含む $30 \mathrm{mM} \mathrm{Tris} \cdot \mathrm{HCl}(\mathrm{pH} 8.0$ ) buffer中で、 $800 \mu \mathrm{g} / \mathrm{ml}$ lysozyme (Boehringer Mannhe im ), $500 \mu \mathrm{g} / \mathrm{ml} \alpha$-amylase( 和光純菜 ) により $37^{\circ} \mathrm{C} 2$ 時間处理する事によって、夏好な フロトフラスト形成を示した。 また、B.Longum M205株 は、 $3 \mathrm{mM} \mathrm{MgCl} 2,0.3 \mathrm{M}$ raffinoset含む $25 \mathrm{mM}$ HEPES( pH7.5) buffer中t: $50 \mu \mathrm{g} /$ mI $\mathrm{N}$-acety! muramidase SG (生化学工丵)により $37^{\circ} \mathrm{C} \quad 1.5$ 時間処理する事によって良好なフロトフラスト形 成を示した。 


\section{Ep.10}

ビフィスス菌のブロトフラスト融合 第2報 ブロトフラストの再生と融合の試み

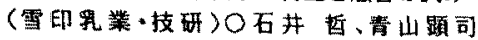
橋場炎、岩崎秦介、中里溥志

1.目的:ビフィスス菌の首㮔技焉として、フロトJ ラスト融合証有力な方法と考えられる。体研究で は、ビフィススス菌のブロトブラスト融合法の碓立 を目的とし、第 1 㪕に綂き、フロトブラスト再生 条件について娭討した。

2.方法：Bifidobacterium pseudolongum SBT2908 を供㢦菌として用いた。ブロナラストの再 生頻度(FR)と有物ブロトブスト出現频度（FAP） は、フロトフラスト惩濁液を高張緩衡で希粎し た後、再生培地に叙涞し、をれそれの培地に出現 したコロニー数と接㮔臀数加ら計算した。再生 条吽は、FRとFAPを指標として設定した。

3.結果：B.pseudolongum SBT2908 のブロトブラス 卜は、 $0.3 M$ O raffinose osmotic stabilizer とする再生培地 MNM-GK涾沫し、 $28^{\circ} \mathrm{C} 、 7$ 日間嫌気 培侌することにより再生した。FRに最も大きく 影謷する因子は、ブロトブラスト調製の際の溶菌 時間であり、容菌時間が長くなるにつれて、FR活 低下した。その他の因子として、再生培地に含 まれる二洒イオン $\left(\mathrm{Ca}^{2+}, \mathrm{Mg}^{2+}\right)$ の溜度执よU゙再生 培地への gelatinの添加、再生時の培圽温度につ いて㛟討したが、いずれむ、あまりFRに影䈏しな かった。現在、B.Pseudolongum SBT2908の種内 フロトフラスト融合について娭討中でる。

3Ep12 晎属間䋖胞融合による大腸菌ブラスミドの 媒気性菌への導入とCMCaseの発現 名大・娟・食工北

陳 ○大宮邦婎、清水样一

1. 目的 R. albus由来のCMCase遗坛子到 $\mathrm{pR} 322 \mathrm{k}$

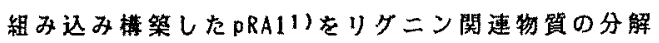
能を有する嫌気性融合株FEM29亿等入し、CMCase活 性を発現させる目的でFEM29株と形算転换株区. Coli ( HB101/pRA1)との異属間䚀胞蜆合を行った。

2. 方法 Fusobacterium varium と Enterococcus faeciumより得られた部合株FE72)の变異株FEM29 (

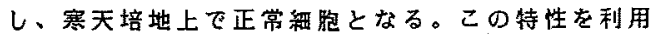
してフロトフラスト化したFEM29とクロラムフェニ

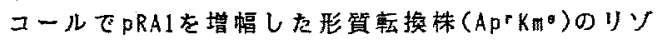
チーム処理により得られたブトブラストとを40\% ボリビニルアルコールで融合させた。

3.結果 FEM29格と形算転换株のブロトブラスト 形成率はそれぞれ99及び92\%、再生率は30及び83\%で

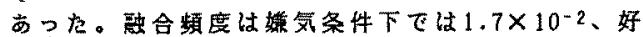

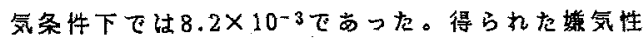

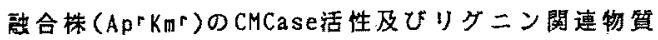
の分解活性注、それぞれ頳椪の約40\%及び50\%加発現

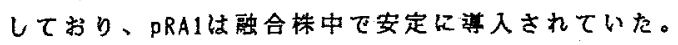
1) Ohniya et al.(1987) Appl.Environ.Microbiol., submitted. 2) Chen et al. (1987) ibid. 53:542-548.

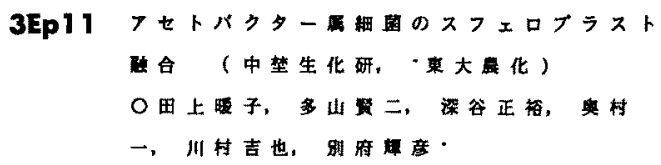

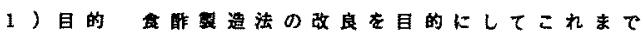

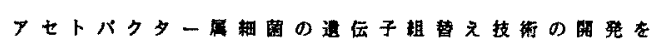

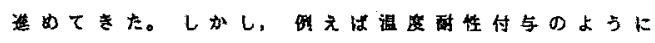

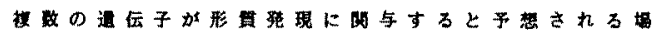

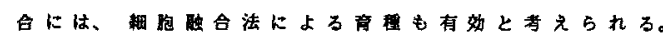

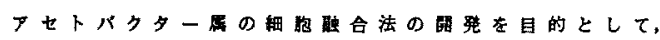

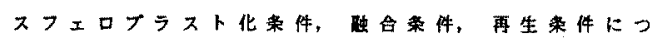
いて討した。

2)方法及䊀果 Acotobacter aceti No.1023株 のアミ) 酸要求性受買株10-8S2(pro-), No.91(pro.10u-), No.2(pro-,cys-) 共践とした。スフェ口

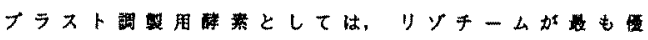
れていた。スフェロブラスト化事は、ショ摭，ソル ヒトールなとが青奻であった。また。ぜキンなと

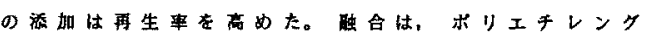

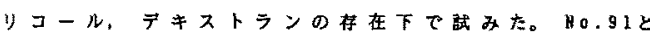

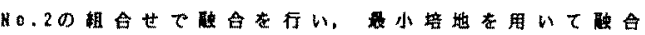

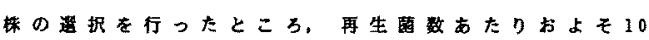

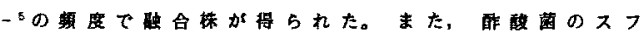

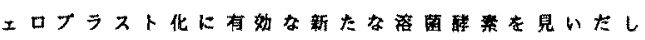
たので阱せて報告する。

3Ep13 䉓気融合法による各種条件下における酻母 枚種籵跑の作成

（島津犁作所）野田幸太郎,十川好志

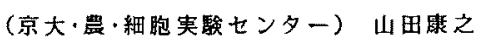

1)目的：演者らは電気バルスによる細胞虽合法の研 究を島津細胞融合装面 S S H - 1 を用いて行ってき

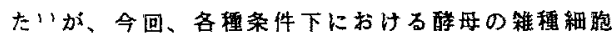
収率について多くの知見を得たので報告する。

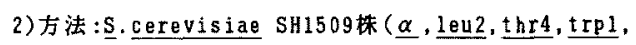

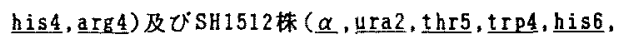
ade1) 22ymolyase-100T处理して各々のブロトフ

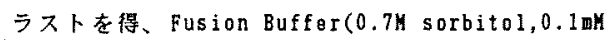

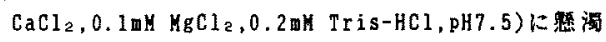
した $\left(5 \times 10^{7}\right.$ 個/n1)。これを等量湿合して電気䖵合 を行った。20〜30分静面後、0.5K KCIを含む最少培 地に散布し、生しだロニー数を訫数した。 3)結果：直流バル又電界强度、バルス帽、バルス数

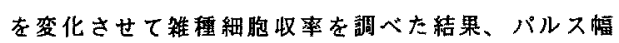
一定ではバルス数が少ない活と、、またバルス数一定 ではバルス幅が短いほど、高い電界強度の領域で雓 程細畹收率の栖大を与えることがわかった。たとえ

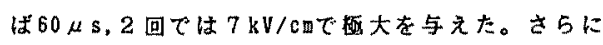
各種奄気条件のほか、Fusion Bufferの浸透压や塩 組成の到器などについても報告する。

1)農芸化学会62年度大会講演要旨集 p.707

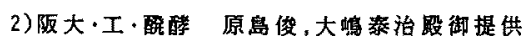




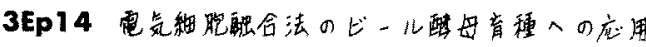

(サ・ポロビール中研)

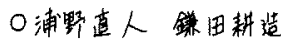

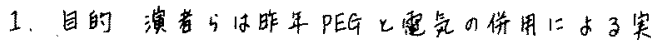

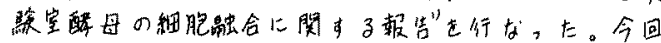

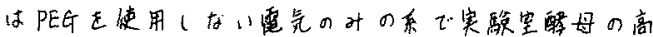

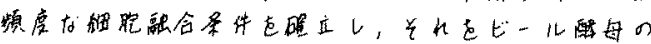

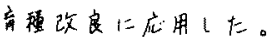

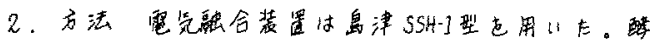

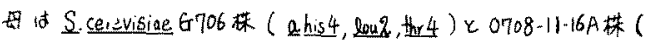

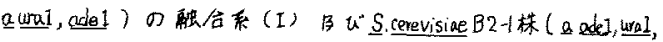

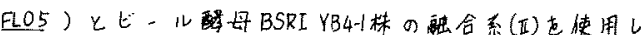

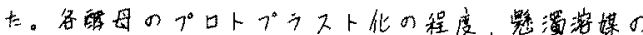

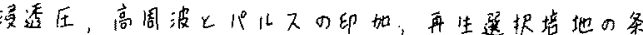

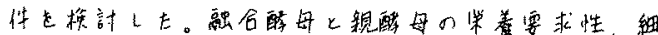

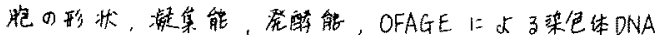
の相遗けどについて調べ。

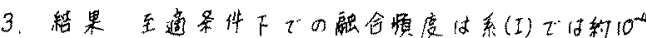

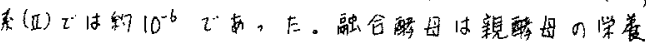

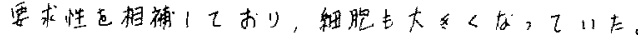

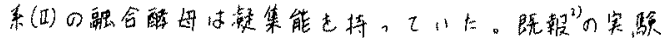

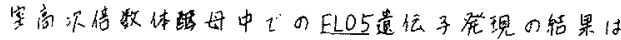

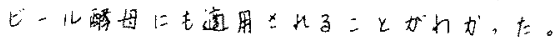

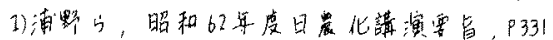

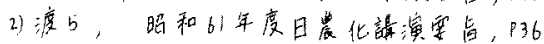

\section{Fal Clostridium acetobutylicum の形實転}

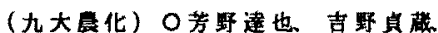
腥方解裁林田策

1.目的アセトン・フタノール菌の分子育璉のた

め、プラスミドベクターの開発态行い、 wholecell を用いた简便な形資䎐换系の開発を就みた。

2. 方法 Chloramphenicol(Cm) 受性の Clostridium acetobuty£icum No.220 仅びNo.86 株の形

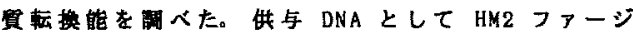
DNA 、指示菌とし $\tau$ C. saccharoperbutylacetonicam N1-4 株を使用したトランスフェクション系 により形賀轱能を梌した。

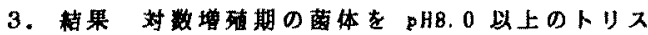
ハッファーにより洗渭した後、ボリエチレングリコ ール6000 存在下 DNA と接䌷させると、No. 220 林

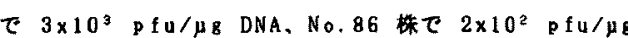
DNA の碩度でトランスフェクションを思めた。 $\mathrm{pH}$

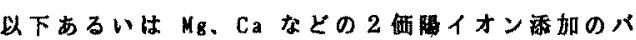
ッファー洗浄によってトランスフェクション能は頙 著に低下した。この椅果に甚づき、No.86 株由来の ブラスミド pCS86'，と pKK232-8との組换えプラス ミド pTY1を用いて No. 220 株を形筫䖝したとこ

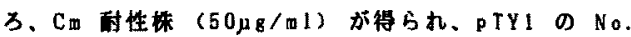

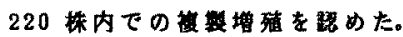

1)吉野 5、昭和 60 年度日量化会大会要旨集 $p 47$

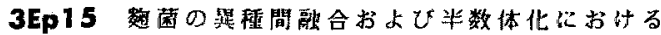
分類的形質と醇素生産特性の举動

(キッコーマン研究本部)

○牛島重臣、大沢学、中台忠信、内田金治 1.目的既報”ては、同種異系統株問の融合上半数体 化に於て、Protease(Prot)と $\alpha$-Amylase(Amyl)o量 的生産性溉して連動して举動する事を㪕告した。 今回は、琵種間融合株及び半数体雑種株に於的る舟

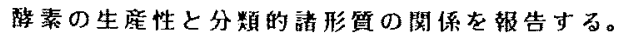

2.方法2'高Prot株A.sojae 2048と高Amyl株A.oryzae

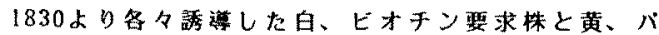
ントテン酸要求株を誘尊し、そのProtoplastを電気 融合し、ベノミルにより半数体化した。形熊恃光頙

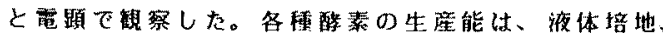
及び酎油数で渭定した。

3.秸果へテロカリオンをUV好理し、安定融合株15株 を得た。融合株で㹥分生子と、Prot泳動夕イブに関 して、0ry型が優性で南った。0ry型分類形質を示す

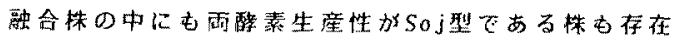
した。半数体株にはマーカ一加見て親型以外に組换 文型も存在した。半数体株中、雨醅素生産性注Soj型

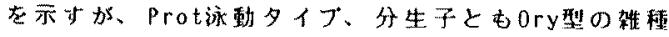
株が得られた。全DNAの制限醇素切断バターンから、 融合、半数休化加確実であつた。耐绦素生産能の遗

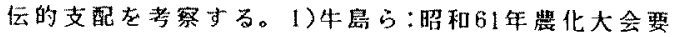
旨集p.111，2)牛島占:昭和62年酸工大会要旨集p.73.

3 Fa2

Agrobacterium tumefaciens $の$ 高頻度形筫轱換 系の確立

（東京理大 応生）○立川㫮一，濑戸裕之

1. 目的 Agrobacterium tumefaciens 2 直接 plasmidt 人する方法として、涷蛣䙌解処理による形算転撸法が知 られている。しかしこの凍結融解法は低頻度であるなど因

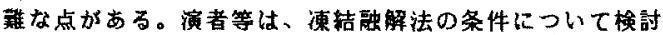
し改良を加之高頻度の形質较换を可能としたのて報告する。 2. 方法おょび結果 A.tumefaciens(LBA4301株)を受容菌 (YEB培地て $1 \times 10^{9} \mathrm{cel} / \mathrm{s} / \mathrm{m} 1$ に調製)とし、その200 $\mu \|$ に $\mathrm{pAB}$ U9(8.7kb kmr pSa ori)t $1 \mu \mathrm{g}$ 添加、ドラ1812-19)-11による

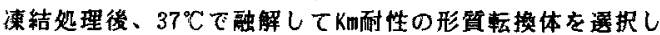
た。従来の方法）は比较的長時閶の凍結融解処理を回行 うが、我々は短時間の処理を行うことにより高頻度の形質 転換を可能とした。この時、凍結融解处理はONA共存下て 行うことが必須であり、処理後DNAを添加しても形質轱换 体は得られな加った。更に、谏結融解を繰り返すと、形算 転換体数はその回数に伴い堌加した。過度の哽結融解の緗 り返しは生苗数の減少を引き起こしたが、100mM Sucrose 添加によりその娍少啲抑えられた。また、形算枟撸頻度に

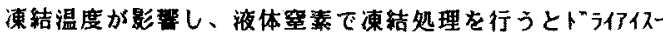

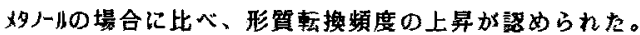
涷轺融解処理は $28^{\circ} \mathrm{C}$ で生育させた対数堌殖期の菌体に対し 行うのが良く、その際、Mg ${ }^{2+}$ 添加が必須であった。改良 された凍結蛼解法による形筫䢂换頻度は、徒来の方法より 数十倍上昇した。また、この方法がこれまでに形䀠枟換法 の確立されていない耕菌に通用できるかどうかも格討する。 1) M.Holster etal. MGG Vol.163, P181-187, 1978. 
$3 F a 3$ 染色体と相同列をもっプラスミドによる 数菌の形質転换

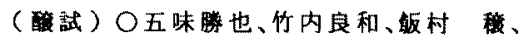
高橋康次郎

1.目的我々は、Aspergillus nidulansのargB道 公子をもっプラスミドによって繁菌 A. oryzae を 形質轱奐することができ、べクターとして利用可能 であることを既に報告した。っこのフラスミドによ る形質轻換頻度は極めて低く、有用道云子を数菌通 层子ライフラリーから逥択する場合には不䔔当であ る。そこで形質転頻度の问上を目的として、数菻染 色体に存在する配列をもつブラスミドを構筑して形 質転行い、若干の知見を得たので赫告する。

2、方法及び結果 A.nidulansのargB透伀子を つプラスミド pSal23 に趋菌のメチオニン要求性を

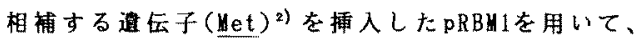
アルギニン要求性株W-2-3を常法に従って形算転換 した。PRBM1による形質転换頻度はpSa123に比へて、2 〜3倍に上昇した。また、Het造伝子内に存在するXhol 部位で直敛状にすると5倍以上に上昇した。形啠転換 体DNAのSouthern hybridizationから、直鎖状ブラス ミドでは大部分が染色体の Net部位に組み込まれて いたが、環状の場合では些以外の非相同部位に組み 込まれていた。更に、形犋転換体から回収したプラス ミドを用いた場合の結果についても報告する。

1) A.B.C. $51,2549(1987), 2)$ A.B.C., $51.323(1987)$

$3 F a 5$

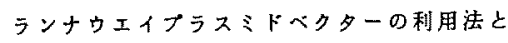

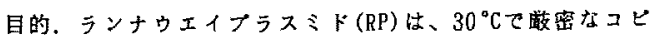

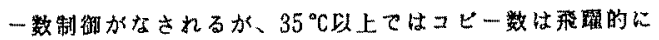
上昇する゙，故にRPは外来遗伝子の発現严として期待され ているが、をの不安定性や培毒の現性久如が指摘されて

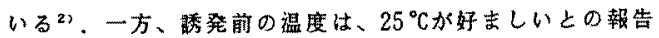
もちる ${ }^{32}$ 。本研究て性、これらの不安定要因を解明し、RP の安定机利用技街を碎立すると伴に、をの発現能について

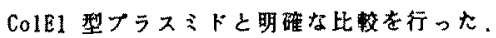

結果. RP. pBEU17よりランナウエ1複整に䐚制的に㑡く配 列を欠失させた後、マルチ括入部位と転写終結因子を㨉入

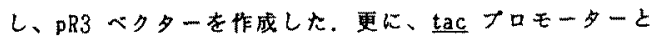

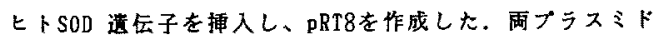

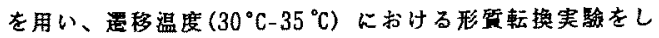
たところ、コビー数低下をもたらす宿主装翼株が出现し、 この解析から、高コヒー数に宽容なK12株として、MC1061 株を荤杓した。次いて、RPを保有するMC1061株を $30^{\circ} \mathrm{C} て ゙$ 培 盖したところ、增殖期と平行してコビー数が上算し、更に、

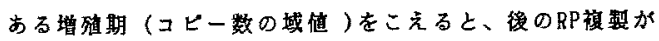

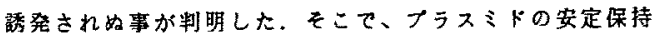
を指磦に、pRT8/MC1061株を培藏したところ、ColE1 型つ ラスミドを用いた場合の12.5倍に相当する生産性 (20\% SOD /全菌体蛋白) 加、再現性良く得られた。

1), Uhlin et al MGG 165, 167 (1978) 2), Nishimura et al J Biotechnol 6, 31 (1987) 3), 曋島 5 化学工 学 49,804 (1985)
3Fa4エタノール凟化性 B.flavunyJ233のHV系の開 発（第2報）電気パルス法によるDNA導入法の 梌討（三萎油化中研）○估藤幸江、小浜恵子、 後藤誠、久留主泰朗、島津光伸、湯川英明 目的) 我々はエタノール資化性 Brevibacterium flavum MJ233の特性を利用したCR Processを提唱し、 さらに組換えDNA伎術を利用して本菌株の育種法の 検討を進めている。今回は本菌株-E.coli系のシャ トルベクターの作成及び本菌株への導入法の検討を 行なったので報告する。

方法）シャトルベクターの作成は MJ233由来のpBV502 (45Kb),pBY-503 (15Kb) とE.coli 系のpHSG398 (2.2kb) を用いた。DNA導入法はフロトブラストー PEG法、電気パルス法を用いた。

結果) pBY-502のHind III断片、pBY-503のkpnl断片を pHSG398の同酵素サイトに連結することにより、シ ヤトルベクターpCRY-2(6.3Kb) 及びpCRY-3 (8.2Kb) を作成した。形質転换株取得に要する日数は電気パ ルス法では2〜3日と大幅に短縮され、得られた形質 転換株中のブラスミドは欠失等の変化もなく、電気 バルス法はコリネ型細菌の有力な形質転換法となる と考えられる。

（1）湯川ら；農化、 $\underline{59}, 279$ (1985)，（2）H.Yukawa et al;:Process, Biochem.,21,164, (1986) , (3) 佐藤ら; 日本発工学会昭和62年度大会講演要旨集、 p.56 (1987)

$3 F a 6$

$$
\begin{aligned}
& \text { Bーガラクトシダーゼ頲伀子を利用した高度好 } \\
& \text { 熱菌プラスミド゙クターの作成 } \\
& \text { （微工研，新日跌化学）。小山芳典，成本茂， } \\
& \text { 古川媌介 }
\end{aligned}
$$

目的我々はこれまでに高度好熱菌 Ihermus属細菌

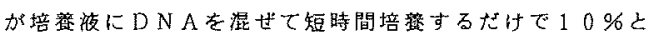
いう高い頻度で形賢䟩换することを明らかにしてきた。し かし薄剂樹性プラスミドがなく、また大腸菌などで使われ ている選択ーーカーも使えないたかにべクターを作成でき

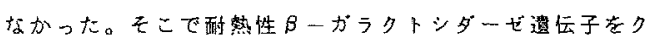
リプティックブラスミドに連結するここにより，形筫朝换 体をX g a lを含む寒天培地上で青色のコロニーとして選 択できるへクターの作成を試みた。

方法と結果 IheImus T 2 株の $\beta$-ガラクトシタ 一ゼ造伝子を含む $4.5 \mathrm{~Kb}$ ○ B g 1 正断片を p UCI8上 にクローニングしたブラスミドSO163とクリブティ

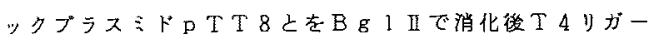
ゼにより連結した。

thermophilus HB27 Pro-株を形笻

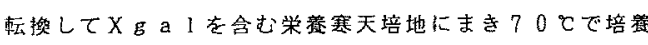
した。落色コロニーの北䓄転换株よりブラスミトを分踓し たところ，p T T 8に日ーガラクトシダーゼ遭伝子がのっ ているものよ，それに加えＵＵ１８がのっている2䍋の ブラスミトが得られた。これらを用いて再び形質転換する と約 $0.5 \%$ 頻度で青色のコロニーが得られた。 


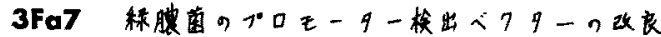

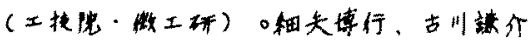

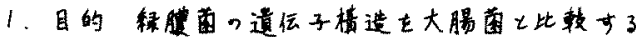

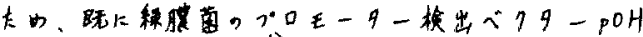

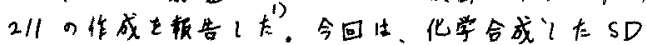

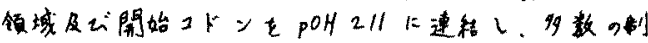

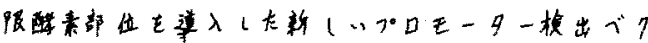
9一を作成し太のて报告する。

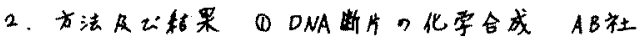
$380 B$ DNA 合成棈で合成。(2)

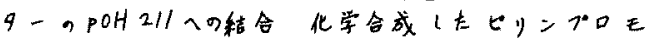

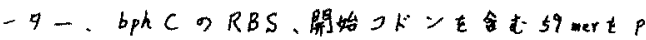

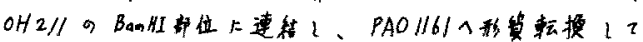

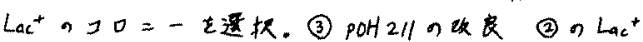
DNAいรピリンプロ と LacZの開始っドンを含み、Hind III

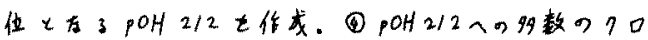

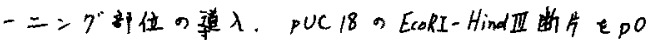

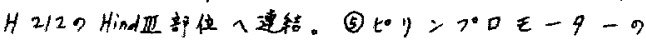

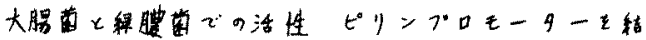

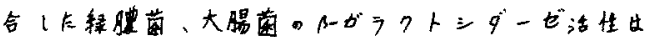

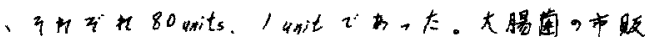

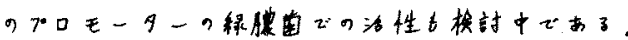
3. 齐献 1) HOSOYA at al $A B C$ 48 3145 '84

$3 F a 9$

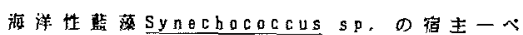

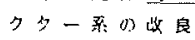

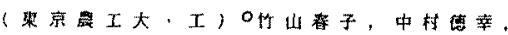

$$
\begin{aligned}
& \text { 始我是 }
\end{aligned}
$$

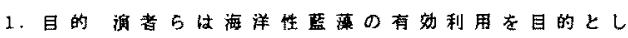

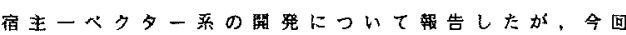
ははこのヘクタ一系の改良を行つた。さらに淡水性監 藻Anacystis nidulans R2 のヘク落と此般した。 2. 方法海洋性蓝落のブスミド抽出はChaurats

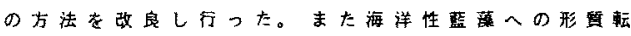

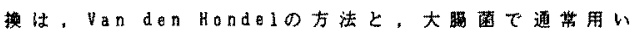

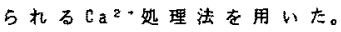

3. 結果海样性蓝 Syechocaccus SF.HKBG 042902

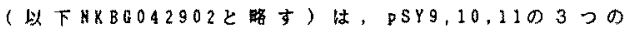
ブラスミドを保有していた。pSY11は2.3kbて、肪d III site 4 ว, EcoRI sitet 2 つ, Acci, Hincllsite

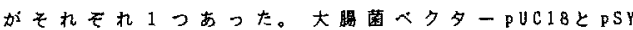
11 のイブリットナラスミド PUSYO2, 新しく槽策し ÆpuSY14(Apr;5.1kb) とA.nidulans R2 のシャ+ル ヘクターPSG111(Apr,CRr;12.8kb)kよるNRBG042902

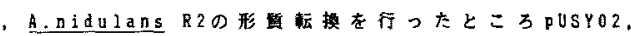

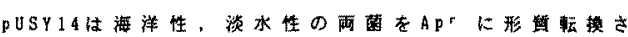

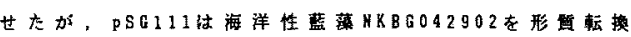
でなが。また，PUSYO2によるNKBG042902の

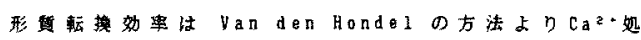
理法加解 1 . 5 倍高加つた。
$3 F a 8$ 海洋性光合成粗四 Rhodopsoudoronas sp.o ベタ一系の放良

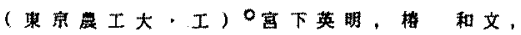
松承是

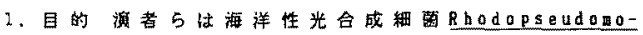

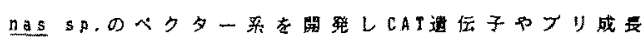
ホルモン遗伝子のクローニンクが可能なとを示 した。今回法海洋性光合成細面へベクタ一者入す

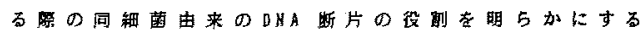

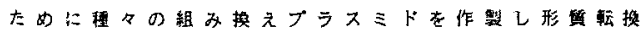

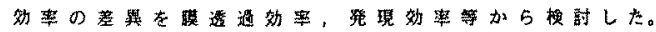
2. 万法及诘果 Rhodopseudomonas SP.NKPB043402 の保持するでラスミFPRD31(3.1kb) BaAHI，PSt

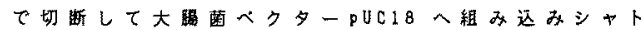
ルベタ-pQD318(Apr;5.0kb), pUD30B(Apr;3.5kb)

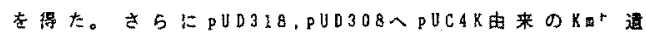
伝子考入して

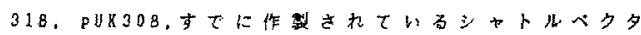

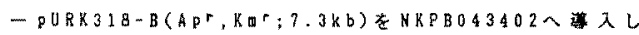
たところ1

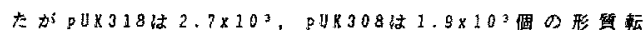

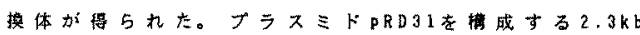

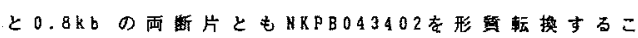

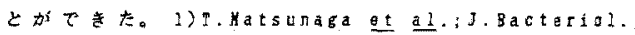
$168.460(1986)$ 2)松永5：昭和62年度日本発酸工学 会䜊演要旨采 $\mathrm{p} 65$.

3Fa10 Brevibacteriumprotophormiaek存在する プラスミドpBP 1 について

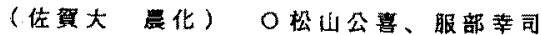
加藤富民雄、村田晃

1、目的 Brevibacteriu四の宿主一ベクター柔の 開発のため、当研究窒保存株の中から5種類のブラ

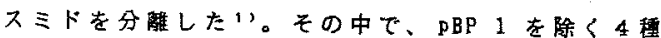
類のブラスミドは選択マ一カーを持たないクリブテ イックなブラスミドであった。今回、B.protophormiae ATCC19271に存在するプラスミドpBP1の 性監について模討した。

2、方法及び結果 PBP 1は約 $33 \mathrm{kbp}$ の大きさで、 ECORIて 3 力所、HindII で 4 力所切断される。親株 をNTGで処理し PBP 1を除去した株 B.protophormiae NQ5 を分離した。親梚と除去株の $\mathrm{K}$ m 的 性を謂べたところ、最小阻止源度はそれそ执400

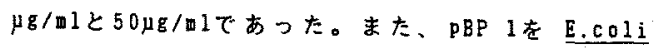
C600 と E.001i JH109に等入し形斯転させたとこ ろ、C600で $4 \times 10^{3} \mathrm{cfu} / \mu \mathrm{g}$ DNAの類度で形筫転換林得

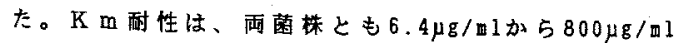
に上算した。以上のことから $\mathrm{pBP} 1$ 法グラム陽性菌 のB.protophordiae とグラム陵性菌のE.coliで權慗 し、禹属でKm耐性の形質を付与することが明らか となった。さらに、PBP 1 のべクター化及び宿主域 を模討した。

1) 本大会昭和 62 年度演繁旨菓 P. 318 
3Fa11 組换えフラスミドpBA61の安定化について

（合问酒精・中研）○赤在雅浩，田中徽， 菊池孝雄，吉武寿一

1.目的 B.licheniformis の耐熱性 $\alpha$ アアミラーゼ 遗伝子を組換えたブスミドpBA61过B.lichenifor mis 中では、部位特異的と思われる久失を生じミ ラーセ生座能(AMY)を失った"。また、B.subtilis 中ではカナマイシン $(\mathrm{Km})$ 非制限下の培䇑では高頻度 に貺落し不安定てあった。そこで pBA61の安定化を 目的に、アミラーゼ遗伝子近㒉の欠失を生じ易い部 分を予为除去し、安定化できか不加梌討した。

2.方法およU゙結果 欠失フラスミドはアミラーゼ造 公子近倍のBgll部位を利用し、PBA61 AEBおよび $\triangle B$ を 作整した。それぞれのナラスミドはB.subtilis M15

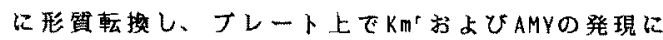
より安定性を試稌した。その結果、PBA61では50\%前

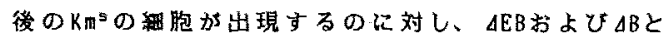
む红99\%以上の相胞加 $\mathrm{Km}^{\mathrm{r}}$ 保持し、安定化した。乙 こて $\Delta \mathrm{EB} B .1$ icheniformis Troo2k 入したところ インタクトな $\triangle \mathrm{EB}$ 保持する株が得られ、安定性加

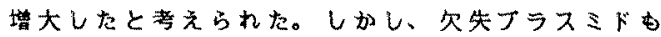
認められ完全で讷なかった。pBA61の BgII部位近憆 の塩基配列を決定したところ昌11部位はへアビン楧 造をとり得る配列内に位㘹していた。

1)赤在ら：日曹化大会講演要旨集，p.28(1986)

3Fa13 放缐菌プラスミド p S L 1 の不和合性撤能 の解析

(明薬大 2 生化) 0 浦辺宏明，小河原宏

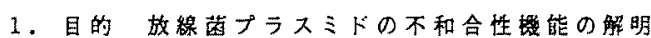
を目的として。その支配領域の限定ならびに解析を 行った。

2. 方法及び結果 Streptomyces lavendulae KCC

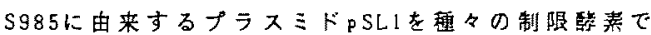
切断しp[J702に遇結したブラスミドを作成した。こ 九租充について 子を付与したPMCP28に対する排除作用を梌討した結

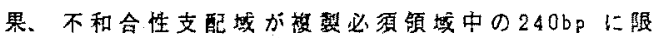
定されたい。ところが、この240bp 断片のみを有す

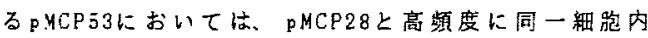
に共存し不和合性の発兒されないことが分かった。

そこで、接域を听487に整入した所、aph遣伝子 の発胃が認めら九、プロ亡ーターの存在が明かとな つた。次に支配項域の槽逜解析を目的として、制限 醅等切断点を利用し合成リンカーを㨉入したプラス ミドを作成した。この㨉入体についてpyCP28との共

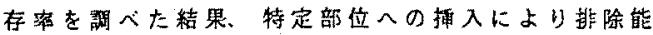
が著しく氐下することが䠐察され、この部位が機能 上重要な役割を担っているものと思われるう。

1)昭和60年费化大会演要旨集 $\mathrm{P} 51$

2) Plasmid 17, 157-163 (1987)

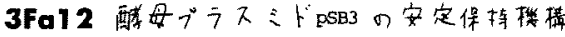

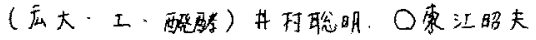

1. 目的 DSB3 は Zygosaccharonyces rouxii \&天然の举

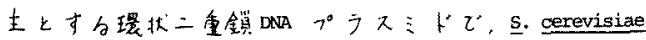
由来の 21 DNA と類似の棤造上の特微を持つ、二几ま での研先上より， PSB3 上の土つの遗伀子(

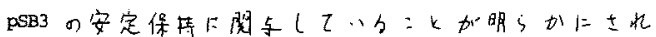
たり。今回は。二和らの遗伝子座物加作用すると椎

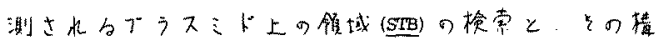
造上の特微走調へた。

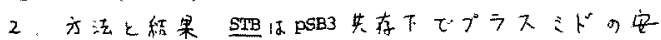

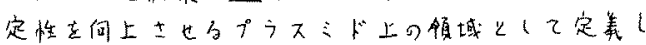

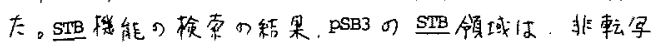
领城の XhoI-BanII閣の912bp内に存在する:とがわが

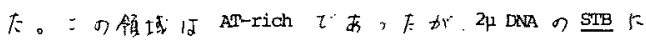

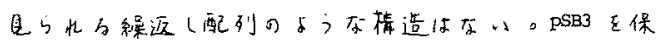

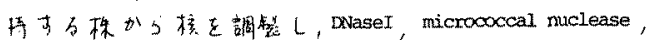

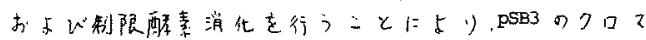
タン楼造を捈討した。フラスミト上の三つの遗伝子

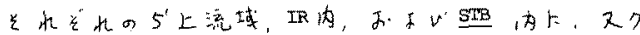

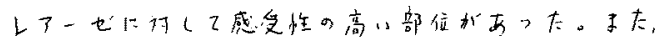

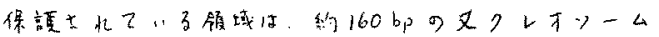
楼造とと,ていることが巾か，た。

1) Toh-e, A. and Itatsu, I. (1985) Nucl.Acids Res. 13, 4267.

3Fa14 放線菌の高勃率プロモーヌ一の满造と艺の 高発现用ベクヌ一への利用

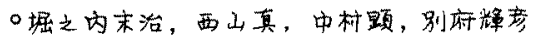

I. 目的我々は，色素生痤を指標とできるプロ モ一夕一梌索用べフヌ一PARC1を用いて，S.gniseus

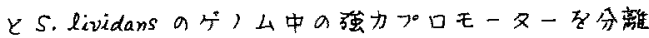
(下文本研究は，放線菌の強力プロモ一タ一の模造 女明らかに1，三儿を放線菌の高登现用べクタ一に 利用する:とを目的とする。高登現ベクタ一は，各

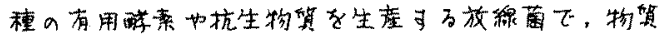

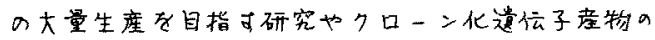
增幅父どを通した生理的研究に有用と者之的丸る。

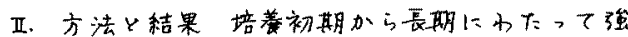
为なプロモーター活性を有するDNA断片の塩基配

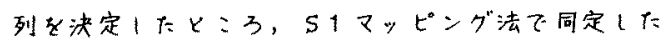
朝写南始部位の 5 塭基上流々，TTGCCG-18 b p TAGCGTKいう $-35,-10$ 楼を有していた。 本7・ロ毛一又一高了ピ一数, 広宿主域ap1J702, pKS11に速結し，下流にュニ一クな各種の制限素 部位を敦け，pSEVジーズの高発理用ベクターを 權筑した。PSEV2を利用りて，S. lividans内でThermus

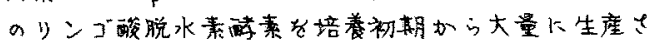
せることが出来た。また，枯草菌のセルラ一也遗伝 子を登理させた埸合，セ儿ラ一ゼは效率よく培地中 下分泌上小た。 
$3 F a 15 A$-factor 1 \& Sereptamyes griseus トレブトマイシンリン酸化酸素意伝子の転

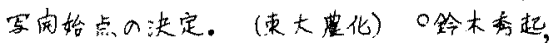
堀元内束治, 品府糧旁

1.目的S.grisend 中ごA-factor

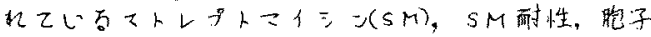

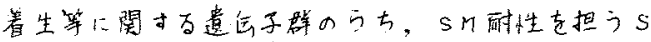

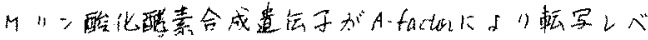
Uご調節され乙しることは前回の大会で述べた。今

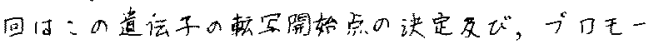

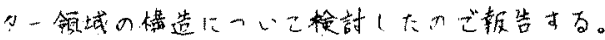

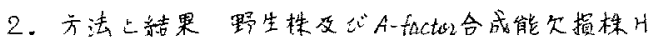

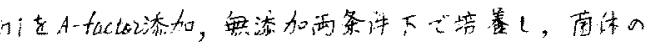

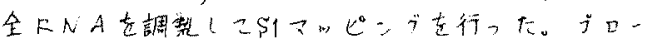

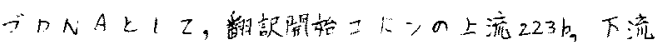

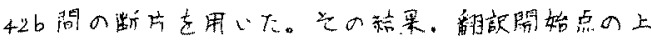

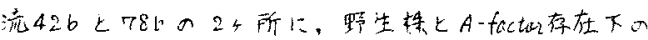

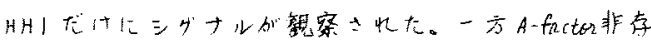

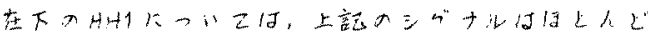

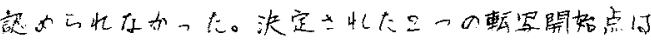

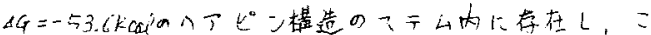

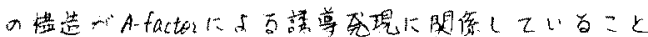

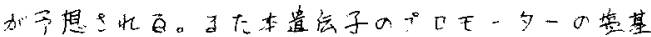

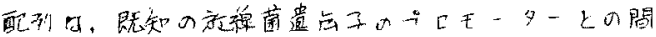

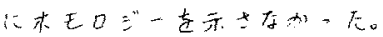

1) 62年度大会要旨集 0625 (1987)

3Fp 1 Pseudomonas putida GAM-1株のカドミウム耐性 橁棈 (第 4 報)

（岐皁大農化，・日本製轵中研）堀津洁章， ○渡辺昌弘，早川僓子，河合啓一，福地彰

1. 目的 先に本菌株のCd耐性が，ブラスミド pGU-100に より支配され，工ネルギー存性のCd排出楼によること を明らかにした。12) 今回は，本菌株のCd而性の発現機棈 に関し，更に検討を加え，その耐性発現加Cdにより誘基さ れる現象を認めたので報告する。

2. 方法 菌体はCdCl 2 添加L-brothを用い，振とう培養し た。菌体内へのCd取り込みは ${ }^{109} \mathrm{Cd}$ 用い，Cd蓄穔量は原 子吸光法により測定した.プラスミドは，アルカリ溶菌法 で抽出し，アガロースゲル電気泳動で確認した。

3. 結果 Cd無添加培羡した本菌株は，3.5mM Cd添加培地

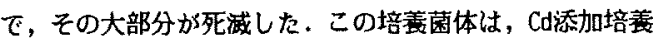
した菌体に比べ，速やかにCdを取り込み，さらに菌体内に 約 2 倍量のCdを畄積しており，Cd排出機能を消失していた。 しかし菌体内 pGU-100量に変化はなく, ブラスミドの脱落 はみられなかった。一方，Cd耐性能を消失した菌体を1nM

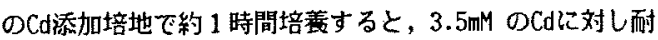
性を示し，耐性の哞現が誘萁されることを諗めた。この誘

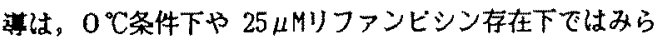
れなかったので, 蛋白合成系が関与していることが示唆さ ht.

1) J.Bacteriol.165,334-335 (1986)

2) 昭和 62 年度 本大会講演要旨勧 p.683
3 Fa16 Streptomyces azureus の自然锈発性 pock形

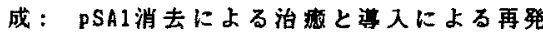

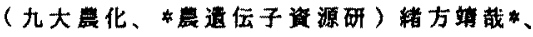
○朴銑棓、三好衯子、吉野具藏、林田晋策 1. 目的 チォストレブトン生産菌 S. azureus の 生型株 (PKO)は は p ck非形成株（recipientまたはlaun） との間で伝達性のpock（C-pock）を形成する他に、 同一荡楼内で不完全ファージ粒子の麾生を伴う自然 誘発性のpock (P-pock) を形成する。本研究怡Ppock形成の要因及び両pockの関連性を明らかにしよ うとするものである。

2. 方法・結果 PSA1プラスミトの自律型と組远み配 列を有するPKO模よりacriflavin処理によって得られ たpock非形成株PKCは目律型のpSA1を欠笑し、組込み 配列を残していた。PKC株には自然橎発的に約10-日の 变異率でP-、C-pock同時形成得塼株が出現した。一 方、 $\mathrm{PSA1}$ の多コピー性变異 PSA1.1を有するPK100株 より自然禖発的に得られたpock非形成株PK100C自 律型も粗込み配列も消失しており、P-及びC-pock形 成復帰株は共に出現しなか力った。PK100C株にPSA1.1 を迸入して作製したC-pock形成転換株PK100aは組込 み配列を持たす、自律型のpSA1.19みを有していた。 PK100a林は分離当初P-Pock形成能を示さなかったが、 数回の移植培によってP-Pockを形成するようにな った。これらの結果はC-pock形成と同㥞にP-pock形 成にもpSA1プラスミドが関与することを示している。

3Fp2

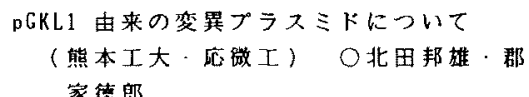
家德即

(目的) Kluyveromyces Lactic 加ら見出された状 キラーDNAプラスミト（pCKL1，2）の袆製に関与する 遭伝子を明らかにする。

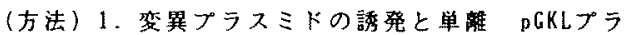
スミトを保有している キラー表現型に異常(今回は弱いキラーを示すもの WK）を示すコロニーを選抜した。フラスミトの異常 の有無老アガロースゲル電気泳劧で調べた。2.变翼 プラスミドの解析 ササンフロットハイフリタイゼ 一ションと制限醅菜による切断に上って欠失領域を 同定した。また、一部の構造解析にはアルカリアカ ロースゲル電気泳動法を用いた。

(結果) UV照射した5000コロニーのキラー検定によつ て3つの怆変異株(KUV-35，110，192)を得た。KUV110

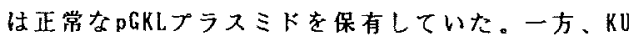
V-35，192kは、pCKLブラスミドの他に変翼フラスミ トが模出された。KUV192の变異フラスミト（粎 $5 \mathrm{~Kb}$ のpK192Lと 2.5KbのpK192S) の满造解析と道伝的举 動から、PGKLフラスミトがコートしている0RF1の逐 伝子は、pGKL1自身の複製に必要であることが結諭さ れた。 
$3 F$ 3 3 耐告性乳酸菌 Pediococcus halophilus から分離したプラスミド

（信州味嘫研）○萱原久考, 安平仁美 （信大織維・态生科）関口㮌一

1. 目的 演者ら洗先に耐程性乳酸菌 Pediococcus halophilusからブラスミドを分離し，そいうう低分 子曹のプラスミドpPHA1〜pPHA7について㪕告した。 今回はこれらのブラスミドの類緑性について相同性 の点から検討した。

2. 方法 プラスミドは前回同樣にBi rnboim\&Doly のラビッドアルカリ法を若干改変して抽出した。

サンブル中に複数のブラスミドを含む場合に法低融 点アガロースゲルにより単ーバンド加ら精製した。 各ブラスミドを32Pラベルしてブローブとし，そ机 ぞれSouthern hibridizationk行った。

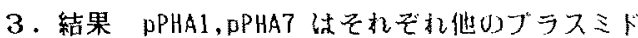
とはhybridを形成しなかった。一方 pPHA2,pPHA5， pPHA6 结p PHA2 pPHA6と弱いながらもhybridを非成 した. pPHA3とрPHAAは互いに強くhybridizationし, pPHA2,pPHA5, pPHA6 と弱<hybrid在形成し，pPHA3， pPHA4 D制限醇素地図加らの結果と一致した。これ らの結果からpPHA1, pPHA2〜pPHA6, DPHATの3グルー ブに分けられた。またpPHAIと口PHA7は相同性は示さ なかったが, 同一株に共存するケースが見ら扎た。

1)松山方：日農化58年度大会要旨p361(1983)

2)惪原占；日農北62年度大会要旨p317(1987)

$3 F p 5$

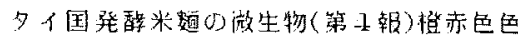
素座生菌のフラスミ卜

（東京農大、蕰化）○高尾哲也、内村泰、 小原面引、小崎道雄

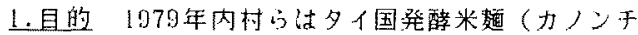

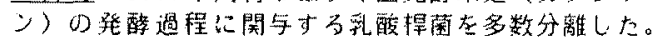
こ机ら分離株の中からコロニーの色調が橙赤色と

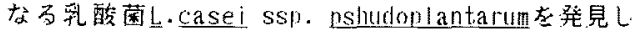
た。本菌の色素産生能は継代、保存培羡に占り失わ

机、回復しないことなとから、発見当初よりつラス

ミドの存在加示嗳さ㧈ていた。そこで本菌のフラス

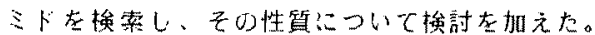

2.方洼 フラフミトはアルカリ法应改变し抽出、ア

ガロースゲル電気泳動、さらにキュアリンク等によ

b娭索在行った。

3.結果上記の方法によりブラスミトの娭萦左行っ た結果、49.35.29.13.12.5k付近に5 本の7ラ又

ミトバンドが娭出された。アクリフラビン、ノボ オシン等に上当キュアリンクの結果、色素歷生能

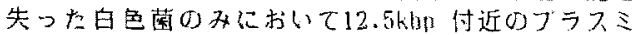
ドハンドの消失、低分子比が認如ら机た。低分子比 したフラスミトバトは11.5king 付近のみに一样に 存在し、他の分子黑のハンド蚞出されなかった。

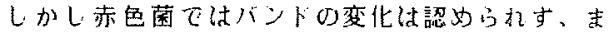
た継代、保存培により生した白色菌で法赤色菌之 同样のフラスミトハント在持つ株と、12.5 han 付近 のバントか低分子化した菌株とが認为られた。

内村引、昭和 55 年度本大会要旨1 125

内村方、昭和 56 年度本大会要旨阳2

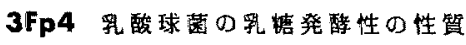

(農水省畜試) ○岡本隆史、藤田泰仁、入江 良三郎

1. 目的乳酸球菌の重要な形質である乳糖発醇性 (Lac) はプラスミド支配であることが知られている か、しacフラスミドの特徽、克るいは梏造の菌株間で の類似性について明らかでない。今回、Lacの不 安定性、ブロテアーゼ(Prt)生㞗能との速関につい て一定の傾向があるか否か㭲討した。また、今一・ gal遗云子のクローニングあ試みた。

2. 方法乳酸球菌 3 理 10 株を供試菌として、高

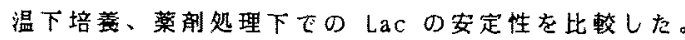
Lac- 株が得られたものについては、ブラスミドバタ ーン、Prt活性を比僌し、Lac ブラミドの同定、 LacとPrtの速関について比较した。また、起源の

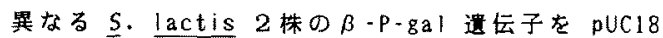
にクローニングし、その棰造を比較した。

3. 結果 $\underline{\text { S. Iactis }, ~ S . ~ d i a c e t y l a c t i s ~ o ~ L a c ~} 4$ 概して不安定であるのに对し、S. cremoris 3 株は いずれむ著しく安定ですっ。占， lactis 5 林、

S. diacetylactis 2 株のうち 4 株までは Lac $^{-}$と同 時にP P r 活性む完全に消失した。しかし、了株につ いては残存Prt活性む为占れ、Lac と P r が画一的なむのでないことが示された。クローニン グされた $\beta$-P-gal 遗伝子含む DNA 断片の大部分 は、同じ構造と考えられる。

$3 F$ 66 担子菌 シイタケ、ヒラタケのミトコンド リア内面鎖状プラスミド(第二報)

(果工大 理) O片橗裕一，油井磨康， 宍开和夫

1. 目的：睌に我々は、担子菌、シイ夕ケ(Lentinus edodes)及びヒラタケ(Pleurotus astreatus)のミト コンドリア内に直鎖状プラスミドを発見、分離精製 した。シイ夕ケからは11kb，七ラ夕ケからは10kb。 9. $4 \mathrm{~kb} の 2$ 種、計 3 種類が得られ、それぞれをPLLE1 pLP01,pLP02 と命名した。これらは全て核、ミトコ ンドリアDNAとは全く相同性を示さなかった。今 回、プラスミド分子について若干の検討を加えたの で報告する。2.方法と結果：ブラスミドの精製は、 分画連心で得られるミトコンドリアを界面活性刘で 溶解後、へキスト33258-CsCl密度勾配遠心法により 行なった。ヒラタケPLP01,pLP02 の場合、プラスミ ドをミトコンドリアから抽出する際にproteinaseK 処理をするか否かで、アガロースダル電気泳動時の 移動度、及び、へキスト33258-CsC1密度勾配遠心に よるDNAのバンド形成において顕著な善が見られ 末端への蛋白筫の関与が示咬された。この現象はシ イタケPLLE1 では見られず、異なった末端棈造を持 つと推定される。現在、ブラスミドのアルカリ処理 に対する举動を調バることで末端構造についてさら に解析を准めている。 ref. 第10回日本分子生物学会年会要旨集 P. 244 